Palimpsest: Journal of Information and Library Science Vol. 11, Issue 1, 2020, page 9-57

\title{
Kesenjangan Digital Akibat Kondisi Demografis di Kalangan
}

\author{
Masyarakat Rural
}

\section{Digital Gap caused by Demographic Condition among Rural Society}

\author{
Renaldy Oktavianoor \\ Departemen Informasi dan Perpustakaan, Fakultas Ilmu Sosial dan Ilmu Politik, \\ Universitas Airlangga \\ Jalan Dharmawangsa Dalam, Airlangga, \\ Surabaya \\ renaldy.oktanianoor-2015@fisip.unair.ac.id
}

\begin{abstract}
Digital gap or digital divide is a problem that emerged in the community because of the development of ICT (information and communication technology) are less prevalent. This problem is often experienced by rural communities, for urban communities first get a chance to feel the impact of the development of ICT infrastructure when compared with rural communities. Ariyanti stated that the digital divide is caused by four factors, infrastructure, skill, language content, and utilization. Therefore, researchers interested in conducting research in Argosari village, Lumajang. This research uses descriptive quantitative method with a sampling technique using accidental sampling. The results of this research found that all respondents own a smartphone, but internet access availability in the village Argosari still poor. Skill owned by villagers of Argosari still much in the learning phase using ICT tools, with a percentage of $64 \%$. The ability of the respondents in understanding the English language content still many expressed very difficult in understanding the English language content on the Internet, with a percentage of $51 \%$. On the utilization of ICT tools, $80 \%$ of respondents have started using their ICT tools for browsing activity. Researchers found that there is a relationship between the age of a person with activities you do while using technological devices; there is a relationship between a person's last education level with their skills in operating the technological features of the device; there is a relationship between education level last person with their skill in operating a search engine; there is a relationship between a person's last level of education with their ability to understand content in English.
\end{abstract}

Keywords: digital divide; rural communities; information and communication technology

\begin{abstract}
Abstrak
Kesenjangan digital atau digital divide merupakan sebuah permasalahan yang muncul di masyarakat karena adanya perkembangan TIK (teknologi informasi dan komunikasi) yang kurang merata. Permasalahan ini kerap dialami oleh masyarakat rural (masyarakat pedesaan), karena masyarakat urban (masyarakat perkotaan) lebih dulu mendapatkan kesempatan untuk merasakan dampak pembangunan infrastruktur TIK jika dibandingan dengan masyarakat rural. Ariyanti menyatakan bahwa kesenjangan digital disebabkan oleh 4 faktor, yaitu faktor infrastruktur, skill, konten bahasa, dan pemanfaatan. Karena itu peneliti tertarik untuk melakukan penelitian di Desa Argosari, Lumajang. Penelitian ini menggunakan metode penelitian kuantitatif deskriptif dengan teknik pengambilan sampel menggunakan accidental sampling. Hasil dari penelitian ini ditemukan bahwa seluruh responden sudah memiliki smartphone, akan tetapi akses internet yang tersedia di Desa Argosari masih buruk. Skill yang dimiliki masyarakat Desa Argosari masih banyak yang dalam tahap belajar menggunakan perangkat TIK, dengan persentase 64\%. Kemampuan para responden dalam memahami konten yang berbahasa inggris masih banyak yang menyatakan sangat kesusahan dalam memahami konten yang berbahasa Inggris di internet, dengan persentase 51\%. Pada bagian pemanfaatan perangkat TIK, sebanyak $80 \%$ responden sudah mulai menggunakan perangkat TIK mereka untuk aktivitas browsing. Peneliti menemukan bahwa terdapat hubungan antara usia seseorang dengan aktivitas yang dilakukan saat menggunakan perangkat teknologi; terdapat hubungan antara jenjang pendidikan terakhir seseorang dengan skill mereka dalam mengoperasikan fitur pada perangkat teknologinya; terdapat hubungan antara jenjang pendidikan terakhir seseorang dengan skill mereka dalam mengoperasikan search engine; terdapat hubungan antara jenjang pendidikan terakhir seseorang dengan kemampuan mereka dalam memahami konten yang berbahasa Inggris.
\end{abstract}

Kata kunci: kesenjangan digital; masyarakat rural; teknologi informasi dan komunikasi

\section{Pendahuluan}

Kesenjangan digital atau digital divide merupakan sebuah permasalahan yang muncul di masyarakat karena adanya perkembangan TIK (teknologi informasi dan komunikasi) yang kurang merata. Permasalahan ini kerap dialami oleh masrayakat rural (masyarakat pedesaan), karena masyarakat urban (masyarakat perkotaan) lebih dulu mendapatkan kesempatan untuk merasakan 
dampak pembangunan infrastruktur TIK jika dibandingkan dengan masyrakat rural (Subiakto, 2013). Permasalahan ini dapat kita temui hampir diseluruh penjuru dunia, seperti yang telah dilampirkan dalam hasil penelitian yang dilakukan oleh Tayo et.al (2015) menemukan bahwa masyarakat rural yang ada pada daerah Ido dan Yewa di Nigeria mengalami dampak dari adanya kesenjangan digital yang membuat mereka mengalami kesulitan dalam mengakses ataupun menyebarkan sebuahinformasi.

Pada penelitiannya Tayo et.al (2015) mengemukakan bahwa terdapat berbagai faktor yang menyebabkan terjadinya kesenjangan digital pada masyarakat rural. Faktor pertama yaitu keterbatasan ekonomi yang menyebabkan kurang mampunya masyarakat untuk membeli komputer ataupun berlangganan pada akses internet, hanya $20 \%$ responden pada penelitian ini yang mampu membeli komputer dan berlangganan akses internet yang menurut mereka cukup mahal. Faktor kedua yaitu minimnya pengetahuan dan kemampuan masyarakat dalam menggunakan komputer ataupun mengakses internet, 90\% responden mengatakan ketika pertama kali menggunakan komputer dan internet mereka merasakan kepuasan, mereka juga memberikan kesan yang positif akan adanya komputer dan internet pada perpustakaan komunitas di daerah mereka. Sekitar $70 \%$ responden mengatakan kehadiran dari TIK merupakan sebuah kemudahan dalam memecahkan permasalahan sehari-hari, berkomunikasi, transaksi bisnis, dan penemuan peluang pekerjaan. Salah satu responden beranggapan bahwa dengan adanya penggunaan e-mail membantu mempermudah para pegawainya dalam menghemat pengeluaran uang yang biasanya di gunakan untuk membayar tagihan telepon jarak jauh, dan juga untuk mempercepat proses penyampaian informasi. Faktor ketiga yaitu terbatasnya tempat yang menyediakan akses internet untuk publik seperti warung internet ataupun perpustakaan umum di daerah negara bagian Ogun. Padahal masyarakat sekitar sangat membutuhkannya untuk berbagai hal. Seperti yang dikatakan oleh $65 \%$ responden, mereka menggunakan komputer dan internet untuk melakukan pencarian pekerjaan, transaksi bisnis, dan sosial media. 95\% responden mengatakan mereka membutuhkan adanya pembangunan fasilitas public yang menyediakan komputer serta akses internet seperti warung internet, perpustakaan umum, ataupun perpustakaan komunitas.

Kesenjangan digital juga di alami oleh masyarakat rural di Indonesia, salah satunya yang ditemukan oleh Ariyanti (2013) pada penelitiannya Ariyanti menyatakan bahwa terdapat berbagai macam faktor yang menyebabkan terjadinya kesenjangan digital. Faktor yang pertama yaitu infrastruktur, minimnya ketersediaan fasilitas pendukung dalam penggunaan teknologi dan akses internet dapat menyebabkan terjadinya kesenjangan digital. Di Indonesia rendahnya angka ketersediaan ataupun pembangunan infrastruktur TIK rata-rata datang dari daerah timur seperti Maluku, Maluku Utara, Nusa Tenggara Timur, Sulawesi Tengah, Sulawesi Tenggara, Papua (Ariyanti, 2013). Faktor yang kedua yaitu skill, tidak hanya keberadaan komputer dan akses internet yang dibutuhkan untuk mengakses atau menyebarkan suatu informasi, namun skill atau kemampuan seseorang dalam menggunakannya juga dibutuhkan agar keberadaan komputer dan ketersediaan akses internet dapat dipergunakan secara maksimal. Rendahnnya angka literasi penggunaan komputer dan internet di Indonesia terjadi di daerah Papua, Maluku Utara, dan Nusa Tenggara Timur (Ariyanti, 2013). Faktor yang ketiga yaitu bahasa pada sebuah konten yang disajikan di internet, masyarakat rural cenderung mengalami kesulitan dalam memahami konten atau informasi yang ada di internet karena kendala bahasa, masyarakat rural akan lebih mudah memahami informasi atau konten di internet yang berbahasakan Indonesia. Hal ini terjadi karena tingkat pendidikan masyarakat rural tergolong cukup rendah untuk memahami informasi yang terdapat dalam suatu konten yang berbahasa asing, seperti hasil data yang dikemukakan oleh BPS Kecamatan Kejajar (2010) terkait rendahnya tingkat pendidikan di Desa Dieng Wetan, dari 1844 jiwa hanya sekitar 246 atau 11,33\% masyarakatnya yang melanjutkan jenjang pendidikannya sampai SMA ataupun peruguruan tinggi. Faktor yang keempat yaitu kurang efisiennya pemanfaatan internet dimana seseorang yang sudah memiliki komputer serta akses internet akan tetapi mereka mengalami kebingungan mengenai "apa yang ingin mereka akses atau cari? Apa yang mau mereka lakukan dengan peralatan teknologi itu?" (Ariyanti, 2013).

Kurang meratanya pengembangan dan penyebaran TIK dimasyarakat menyebabkan adanya kesenjangan digital terutama di kalangan masyarakat rural. Jika dilihat dari segi pertumbuhan pengguna internet, Indonesia mengalami pertumbuhan setiap tahunnya, terbukti dari hasil survey yang dilakukan oleh Asosiasi Penyelenggara Jasa Internet Indonesia (APJII) pada tahun 2016 angka pengguna internet di Indonesia hanya sekitar 132,7 juta jiwa, ini setara dengan 51,8\% populasi masyarakat Indonesia pada tahun 2016. Pada hasil survey APJII di tahun 2017 terlihat peningkatan angka pengguna internet di Indonesia menjadi 143,26 juta jiwa, setara dengan 54,68\% dari total masyarakat Indonesia di tahun 2017. Namun jika kita berfokus pada kalangan masyarakat rural, pengguna internet di kalangan masyarakat rural masih terbilang cukup rendah jika dibandingkan 
dengan masyarakat urban. Hal ini dudukung oleh hasil survey yang di lakukan oleh APJII pada tahun 2017 yang menemukan bahwa penetrasi pengguna internet di kalangan masyarakat rural hanya mencapai $48,25 \%$, angka ini cukup jauh jika dibandingkan dengan penetrasi pengguna internet di kalangan masyarakat urban yang mencapai $72,41 \%$. Angka ini tentunya menjadi gambaran bahwa kurang meratanya penyebaran TIK dimasyarakat Indonesia. Rendahnya angka kepemilikan dan penggunaan teknologi di masyarakat rural merupakan salah satu alasan terjadinya kesenjangan digital, berdasarkan data temuan dari penelitian yang dilakukan oleh Kementerian Komunikasi dan Informasi Republik Indonesia (KOMINFO) pada tahun 2016 hanya sekitar 26,3\% rumah tangga yang tinggal di daerah rural memiliki alses terhadap perangkat TIK.

\section{Kesenjangan Digital}

Kesenjangan digital atau digital divide merupakan suatu gap antara individu, rumah tangga, bisnis, dan area geografi pada level sosial-ekonomi yang berbeda terkait kemampuan mereka untuk mengakses TIK (tekonologi informasi dan komunikasi), serta dalam hal penggunaan internet untuk berbagai aktivitas (OECD, 2001). Selain itu Van Dijk (2006) juga menjelaskan bahwa kesenjangan digital terjadi karena adanya ketidaksamaan kepemilikan teknologi atau akses internet antar individu yang menimbulkan munculnya suatu gap. Fenomena kesenjangan digital ini merupakan sebuah permasalahan yang kerap terjadi di era digital saat ini, dimana kurang meratanya penyebaran dan pembangunan TIK menyebabkan terhambatnya kesempatan masyarakat untuk mengakses dan menggunakan TIK tersebut. Keterhambatan ini juga nantinya akan menyebabkan ketidaksiapan masyarakat dalam menerima serta menggunakan perangkat TIK yang semakin canggih seiring waktu berjalan.

Fenomena kesenjangan digital terjadi tidak hanya pada kalangan masyarakat rural (pedesaan), namun juga kerap terjadi pada kalangan masyarakat urban (perkotaan). Namun fenomena kesenjangan digital yang terjadi di kalangan masyarakat rural cenderung lebih banyak jika dibandingkan dengan masyarakat urban. Rendahnya angka kepemilikan dan penggunaan teknologi di masyarakat rural merupakan salah satu alasan mengapa masyarakat rural tingkat kesenjangan digitalnya lebih tinggi jika dibandingkan dengan masyarakat urban (KOMINFO, 2016). Menurut Ariyanti (2013) terdapat 4 faktor yang menyebabkan terjadinya kesenjangan digital, yaitu infrastruktur, skill, konten bahasa, kurang efisien pemanfaatan internet.

\section{Infrastruktur}

Infrastruktur merupakan sebuah fasilitas pendukung dalam mengakses atau menggunakan suatu TIK, infrastruktur yang dimaksud dapat berupa listrik, internet, serta perangkat keras (hardware) seperti komputer, laptop ataupun smartphone (Ariyanti, 2013). Hal ini hampir sama seperti konsep yang dikemukakan oleh Van Dijk (2012) mengenai kesenjangan akses fisik dan materi terhadap teknologi informasi merupakan permasalah kesenjangan akses yang terjadi berdasarkan tingkat distribusi sumber daya. Distribusi sumber daya yang dimaksud disini yaitu ketersediaan hardware dan software. Ketersediaan dan pembangunan infrastuktur TIK di daerah pedesaan sangatlah kurang, masih banyak daerah-daerah pedesaan di Indonesia yang tidak memiliki infrastuktur TIK, yang menyebabkan mereka kesulitan untuk mengakses teknologi.

Ariyanti (2013) menyatakan bahwa sejak 2008 pemerintahan Indonesia telah berproses dalam mengatasi permasalahan kesenjangan digital terkait dengan faktor infrastruktur. Pemerintah membuat sebuah program yang bernama Kewajiban Pelayanan Universal (KPU), program ini melakukan kerja sama dengan berbagai pihak yang dapat menunjang dan mencapai keberhasilan akan program ini. Objek dari program ini yaitu agar desa dan kecamatan yang berada di daerah terpencil dan belum tersentuh akses jaringan atau internet, kelak nantinya pada tahun 2025 daerahdaerah terpencil ini dapat mendapatkan dan menikmati akses telepon, dan akses internet.

\section{Skill}

Skill atau kemampuan seseorang dalam menggunakan perangkat teknologi sangatlah dibutuhkan agar keberadaan komputer dan ketersediaan akses internet dapat dimanfaatkan secara maksimal. Kurangnya kemampuan digital seseorang disebabkan dari hasil rendahnya pendidikan atau kurangnya pelatihan dalam menggunakan perangkat TIK (Putri, 2018). David (2015) juga menemukan hal yang sama pada hasil penelitiannya, bahwa salah satu alasan mengapa masyarakat rural banyak yang tidak tahu dan tidak memiliki skill dalam menggunakan teknologi dikarenakan sekolah yang ada di daerah rural bagian negara Enugu Nigeria tidak memiliki fasilitas laboratorium yang menyediakan teknologi. Kondisi tersebut tentunya juga dialami oleh masyarakat rural yang 
ada di Indonesia seperti yang disebutkan dalam hasil penelitian yang dilakukan oleh Mukhlis (2011), bahwa tingkat pendidikan disalah satu Desa di Indonesia yaitu Dieng Wetan masih tergolong cukup rendah karena hanya sedikit dari masyarakat desa tersebut yang melanjukan pendidikannya sampai SMA ataupun perguruan tinggi. Pada hasil penelitian yang di lakukan Tayo et.al (2015), ditemukan bahwa hampir seluruh responden penelitiannya mengharapkan adanya pelatihan terkait peningkatan skill dalam menggunakan komputer serta mengakses internet.

\section{Konten Bahasa}

Konten dan informasi yang ada di dunia internet umumnya terdiri dari berbagai ragam bahasa negara yang ada diseluruh dunia. Masyarakat rural cenderung mengalami kesulitan dalam memahami konten atau informasi yang ada di internet karena kendala bahasa. Masyarakat rural di Indonesia sendiri akan lebih mudah memahami sebuah informasi jika berbahasakan Indonesia. Hal ini terjadi karena tingkat pendidikan masyarakat rural tergolong cukup rendah untuk memahami informasi pada dunia internet yang umumnya berbahasa asing. Menurut Mukhlis (2011) di Indonesia sendiri tingkat pendidikan pada sebuah masyarakat rural masih tergolong rendah, karena hanya sedikit dari masyarakat rural yang melanjutkan jenjang pendidikannya sampai SMA ataupun yang lebh tinggi.

Menurut Ariyanti (2013) pada sebuah daerah yang memiliki pendidikan lebih tinggi maka akan lebih mudah dalam memahami sebuah konten yang berbahasa asing dibandingkan dengan daerah yang memiliki pendidikan lebih rendah. Banyak dari masyarakat rural Indonesia yang tidak dapat memahami suatu konten atau informasi tersebut ketika berbahasakan asing. Oleh karena itu konten yang berbahasa Indonesia dapat mempermudah masyarakat rural dalam memahami maksud dari informasi yang terdapat pada suatu konten di Internet.

\section{Pemanfaatan}

Penyebab kesenjangan digital tidak hanya terjadi karena keterbatasan infrastuktur, skill, konten bahasa, akan tetapi pemanfaatan internet dengan baik dan benar juga merupakan salah satu faktor. Pemanfaatan teknologi juga merupakan salah satu komponen penting yang dapat digunakan untuk mengetahui apakah ada kesenjangan digital didalam suatu daerah. Kondisi demografi individu seperti usia, tingkat pendidikan, dan tempat tinggal menjadi faktor yang mempengaruhi perbedaan pemanfaatan teknologi informasi (Van Deursen \& Van Dijk, 2013). Meskipun beberapa TIK sudah masuk pada desa- desa yang ada di Indonesia dan kebanyakan masyarakatnya sudah memiliki perangkat dan akses internet, akan tetapi masyarakat rural masih belum bisa memaksimalkan kesempatan ini untuk menggunakan dan memanfaatkan TIK dengan benar dikarenakan minimnya pengetahuan masyarakat rural terkait dengan TIK dan jaringan internet (Subiakto, 2013). Individu dengan tingkat pendidikan kebawah cenderung memanfaatkan teknologi informasi untuk hal-hal yang bersifat hiburan (Mantyastuti, 2016). Sedangkan individu dengan tingkat pendidikan tinggi memanfaatkan TIK untuk hal-hal yang berguna seperti berkomunikasi, transaksi bisnis, pencarian pekerjaan, serta informasi untuk memecahkan pemersalahan sehari-hari.

\section{Akses Informasi}

Akses informasi merupakan kemudahan yang diberikan kepada seseorang atau masyarakat untuk memperoleh informasi publik yang dibutuhkan (Depkominfo, dalam: Saefi 2015). Akses informasi dapat dikatakan sebagai jembatan yang menghubungkan sumber informasi sehingga informasi yang dibutuhkan oleh setiap individu dapat terpenuhi (Saefi, 2015). Pada era informasi saat ini, hak atas akses terhadap informasi telah menjadi hak dasar bagi setiap orang. Namun dibalik hak dasar ini terdapat suatu kesenjangan antara masyarakat yang mempunyai akses terhadap informasi dan masyarakat yang tidak mempunyai akses informasi. Untuk mendapatkan informasi yang baik diperlukan media yang baik, agar informasi yang didapatkan menjadi lebih akurat, tepat waktu, relevant, dan lengkap (Surtabi, 2005 dalam: Saefi 2015). Pentingnya hak atas informasi telah dijamin dengan adanya konstitusi dalam UUD 1945 Pasal 28F: "Setiap orang berhak untuk berkomunikasi dan memperoleh informasi untuk mengembangkan pribadi dan lingkungan sosialnya, serta berhak untuk mencari, memperoleh, memiliki menyimpan, mengelola, dan menyampaikan informasi dengan menggunakan segala jenis saluran yang tersedia".

Masyarakat yang tidak mempunyai akses informasi merupakan masyarakat yang tidak mampu untuk memiliki ataupun mengakses informasi yang ada diduniar luar, umumnya masyarakat rural lebih sering mengalami permasalahan untuk mengaksess informasi. Seperti hasil temuan yang 
ditemukan oleh Chisenga et.al (2007), para peternak yang berstatus sebagi masyarakat rural menyatakan kalau mereka memperoleh dan saling berbagi informasi melalui perkumpulan sesama peternak saja, baik itu melalui ditambah dengan surat kabar, seminar kecil para peternak, ataupun petermuan para peternak saja. Padahal di dunia luar ataupun internet banyak sekali informasi yang sangat berguna bagi para peternak untuk mengembangkan peternakannya serta lahan bisnis mereka untuk berdagang, akan tetapi mereka malah mengalami keterbatasan akses informasi karena tidak adanya tersedia infrastuktur ataupun fasilitas untuk mengakses dunia internet di daerah tempat mereka tinggal, selain itu juga mereka tidak mampu untuk membeli peralatan komputer yang cukup mahal jika dibandingkan dengan pendapatan hasil kerja mereka.

\section{Masyarakat Rural}

Masyarakat rural atau masyarakat pedesaan merupakan sekelompok masyarakat yang memiliki hubungan lebih mendalam dan erat, serta sistem kehidupan yang umumnya berkelompok dengandasar kekeluargaan (Huzaini, 2014). Soekanto (2006) menyatakan bahwa masyarakat pedesaan mempunyai hubungan yang lebih erat dan lebih mendalam ketimbang hubungan mereka dengan warga masyarakat pedesaan lainnya. Sistem kehidupan masyarakat desa pada umumnya berkelompon atas dasar sistem kekeluargaan dengan mata pencariannya yang pada umumnya seorang petani. Masyarakat desa juga ditandai dengan kepemilikikan ikatan perasaan batin yang kuat sesama warga desa. Perasaan tersebut merupakan suatu perasaan antar setiap anggota masyarakatnya yang bernilai sangat kuat dan pada hakekatnya bahwa seseorang merasa merupakan bagian yang tidak dapat dipisahkan dari masyarakat itu sendiri dimanapun mereka hidup, seta mempunyai perasaan bersedia untuk berkorban setiap waktu demi masyarakatnya karena beranggapan mereka sama sebagai masyarakat yang saling mencintai, menghormati, dan mempunyai hak tanggung jawab yang sama terhadap keselamatan dan kebahagiaan dalam bermasyarakat (Huzaini, 2014).

\section{Metode Penelitian}

Penelitian ini dilakukan di Desa Argosari, Kecamatan Senduro, Kabupaten Lumajang, dengan masyarakatnya sebagai populasi. Penelitian ini menggunakan metode kuantitatif deskriptif yang bertujuan untuk menggambarkan keadaan atau kondisi dan berbagai faktor yang muncul di dalam masyarakat yang menjadi objek penelitian (Bungin, 2005). Teknik pengambilan sampel yang digunakan dalam penelitian ini yaitu accidental sampling. Accidental sampling merupakan sebuah teknik pengambilan sampel yang diperoleh secara kebetulan pada saat pengambilan data dilakukan. Jumlah sampel pada penelitian ini adalah 100 responden, hal ini dilakukan berdasarkan pendapat yang disampaikan oleh Aaker (1995), karena populasi di dalam penelitian ini dianggap sama yaitu warga Desa Argosari, maka sampel yang digunakan adalah 100 responden. Pada penelitian ini peneliti menggunakan teknik pengumpulan data yang diambil dari dua bagian yaitu data primer (data dari hasil penyebaran kuesioner) dan data sekunder (data dari penelitian sebelumnya, observasi, dan wawancara singkat). Peneliti melakukan proses pengolahan data menggunakan bantuan program aplikasi SPSS yang bersifat analisis deskriptif dan analisa hasil dari output perhitungan berupa frekuensi dari hasil tabel silang atau crosstab.

\section{Pembahasan}

Gambaran Kesenjangan Digital dari Aspek Infrastruktur, Skill, dan Konten Bahasa di Kalangan Masyarakat Rural

\section{a. Infrastruktur di Desa Argosari}

Berdasarkan data yang telah ditemukan di lapangan, peneliti menemukan bahwa sebagian besar warga desa Argosari sudah memiliki perangkat teknologi seperti smartphone, laptop, tablet. Ditemukan bahwa seluruh responden atau $100 \%$ sudah memiliki smartphone masing-masing. Hasil ini berbeda dengan hasil penelitian yang dilakukan oleh Hadiyat (2014) di Kabupaten Wakatobi, pada penelitiannya Hadiyat menemukan bahwa masyarakat di Kabupaten Wakatobi tergolong sedikit dalam hal kepemilikan perangkat teknologi, kebanyakan masyarakatnya masih menggunakan handphone biasa yang hanya bisa digunakan untuk mengirim pesan dan melakukan panggilan. Hadiyat juga menyatakan hal ini disebabkan karena masyarakat Kabupaten Wakatobi masih banyak yang status perkonomiannya menengah kebawah dan menyebabkan mereka 
menganggap akses dan kepemilikan perangkat TIK masih belum menjadi suatu kebutuhan. Tayo et.al (2015) hasil penelitiannya juga menemukan hal yang serupa dengan penelitiannya Hadiyat, bahwa masyarakat rural di Nigeria masih banyak yang belum mampu membeli perangkat TIK ataupun berlangganan akses internet.

Data yang membuktikan hampir seluruh warga desa Argosari yang sudah memiliki smartphonenya sendiri membuktikan bahwa kepemilikan perangkat teknologi bukan yang menjadikan adanya kesenjangan pada bagian infrastruktur masyarakat desa Argosari, akan tetapi kurang lancarnya suatu jaringan atau akses internet yang ada di desa tersebutlah yang menyebabkan adanya kesenjangan digital dari aspek infrastruktur di desa Argosari. Alasan mengapa ketersediaan akses jaringan di desa Argosari masih tergolong kurang lancar, karena di desa ini hanya terdapat 1 provider saja yang menyediakan jaringan internet yaitu telkomsel. Tidak hanya itu saja yang menjadi permasalahan bagi warga desa Argosari, akan tetapi tidak sampainya akses jaringan untuk beberapa dusun yang ada dibagian atas pegunungan sekitar desa juga menjadi alasan mengapa desa Argosari mengalami permasalahan kesenjangan digital pada aspek infrastruktur. Hasil ini didukung oleh hasil probing salah seorang responden yang menyatakan bahwa:

\begin{abstract}
"disini sudah ada akses internet mas, cuman baru ada telkomsel aja, belum lagi kalau kata orang-orang dikecamatan kalau paket internet dari telkomsel tergolong cukup mahal kalau dibandingkan sama kartu-kartu lainnya. Selain itu juga untuk dusun-dusun yang bagian atas itu mas, masih ada sebagian yang belum nyampe sinyal telkomselnya. Jadi ya kadang mereka turun ke dusun bawah sini atau kewarung-warung dikecamatan untuk menikmati akses internet"
\end{abstract}

Meskipun sinyal di desa Argosari masih tergolong kurang lancar, ada salah seorang warganya yang menyediakan fasilitas warung yang menyediakan fasilitas internet berupa layanan wifi. Sebuah fasilitas yang menyediakan layanan internet disuatu desa sangatlah penting dalam menunjang dan memenuhi kebutuhan informasi masyarakat desa (tayo et.al, 2015). Warung yang menyediakan fasilitas internet benar saja ramai dikunjungi oleh masyarakat warga desa Argosari yang membutuhkan akses internet untuk melakukan berbagai macam kegiatan.

\title{
b. Skill Masyarakat Desa Argosari dalam Menggunakan Perangkat Teknologi dan Mengoperasikan Fitur/Aplikasi
}

Data yang dapat menggambarkan masih rendahnya skill masyarakat desa Argosari dalam menggunakan perangkat teknologi sebanyak $64 \%$ responden menyatakan bahwa mereka masih dalam tahap pengenalan atau belajar dalam menggunakan perangkat teknologi. Peneliti juga menemukan bahwa kemampuan masyarakat desa Argosari dalam mengoperasikan fitur/aplikasi pada perangkat teknologi masih tergolong rendah, sebanyak $49 \%$ responden masih dalam tahap pengenalan atau belajar dalam mengoperasikan fitur/aplikasi yang ada pada perangkat teknologi. Bahkan kalau kita lihat hasil 37\% responden masih kurang mampu dalam menghubungkan perangkat teknologinya dengan internet, dan sekitar 5\% dari total responden sama sekali tidak mampu menghubungkannya. Kurangnya skill dalam menggunakan perangkat teknologi ini didukung oleh pernyataan salah saturesponden:

"Saya masih belajar-belajar gitu mas menggunakan smartphone, sekarang saya baru bisa bales pesan whatsapp dari teman sama browsing sedikitsedikit aja. Bahkan kadang saya dibantu teman saya untuk beli paketan internet ataupun nyambungin smartphone saya ke wifi kalo lagi d iwarungnya pak Budi"

Seluruh responden sudah memiliki aplikasi web browser Google Chrome, akan tetapi $31 \%$ responden masih belum mampu dalam menggunakan atau mengoperasikan Google Chrome tersebut, bahkan ada sekitar $18 \%$ responden yang tidak mampu sama sekali dalam mengoperasikan aplikasi web browser tersebut. Masih banyaknya responden yang kurang mampu (31\%) dan tidak mampu (17\%) dalam mengakses internet. Bukan cuman itu saja, untuk kemampuan mengoperasikan searchengine responden pun masih tergolong rendah dan kurang merata karena ada sebanyak $31 \%$ responden yang kurang mampu dan $17 \%$ responden yang tidak mampu sama sekali dalam mengoperasikan fitur search engine. Hal ini sejalan dengan apa yang disampaikan Tustin et.al (2012) bahwa kepemilikan jenis TIK saja tidak cukup untuk menutupi masalah kesenjangan digital jika tidak diimbangi dengan keterampilan atau kemampuan dalam mengoperasikannya TIK tersebut. Selain itu salah seorang responden juga memberikan pernyataan 
yang menunjukkan masih kurangnya skill atau kemampuan mereka dalam mengoperasikan fitur search engine:

"di smartphone saya sudah ada aplikasi google chromenya mas dari sewaktu awal beli, tapi saya bingung gimana makainya, saya juga jarang banget pakai buat google atau cari-cari info gitu. Biasanya saya dapat info dari teman-teman diladang atau temanteman di Whatsapp saja mas, makanya saya gak terlalu pandai bermain google chrome ataupun buka google buat cari informasi”

\section{c. Kemampuan Konten Bahasa Masyarakat Desa Argosari}

Peneliti menemukan bahwa hampir seluruh responden dari masyarakat desa Argosari sudah menguasai bahasa Indonesia. Sekitar $46 \%$ orang mengaku telah menguasai bahasa Indonesia, dan 49\% mengaku sangat menguasai bahasa Indonesia. Hal ini tentu berpengaruh kepada tingkat pemahaman masyarakat desa akan konten atau informasi berbahasa Indonesia yang ada di Internet, seperti yang dikatakan oleh Ariyanti (2013) bahwa masyarakat rural akan lebih mudah memahami informasi atau konten di internet yang berbahasakan Indonesia. Sebanyak 38\% responden mengaku mudah dalam memahami konten yang berbahasa Indonesia, dan $46 \%$ responden mengaku sangat mudah dalam memahami konten yang berbahasa Indonesia. Terdapat sekitar 16\% responden yang berupa anak-anak kecil yang susah memahami konten berbahasa Indonesia dikarenakan faktor kosakata yang mereka miliki masih sedikit sehingga terkendala dalam memahami makna dari suatu kalimat (De Marco \& VernonFeagans, 2013).

Terkait pemahaman sebuah konten yang berbahasa Inggris, maka seseorang terlebih dahulu perlu menguasai bahasa Inggris. Rendahnya tingkat penguasaan bahasa Inggris masyarakat desa Argosari, sekitar 51\% orang kurang menguasai bahasa Inggris, dan 37\% orang sama sekali tidak menguasai bahasa Inggris. Hal ini terjadi karena bahasa sehari-hari yang digunakan dalam bertetangga masyarakat desa Argosari yaitu bahasa Jawa dan bahasa Indonesia, seperti yang dikatakan oleh Lloyd \& Hertzman (2010) bahwa kemampuan seseorang dalam berbahasa bergantung dengan bahasa sehari- hari apa yang digunakan masyarakatnya dalam bertetangga. Rendahnya tingkat penguasaan bahasa Inggris masyarakat desa Argosari, tentu saja berdampak akan kemampuan masyarakatnya dalam memahami konten di internet yang berbahasa Inggris. Sebanyak $40 \%$ responden menyatakan susah dalam memahami konten berbahasa Inggris, dan juga terdapat $51 \%$ responden yang sangat kesusahan dalam memahami konten di internet yang berbahasa Inggris.

d. Pemanfaatan Masyarakat Desa Argosari Terhadap Perangkat Teknologi dan Informasi

Pada penelitian ini menemukan bahwa masyarakat desa Argosari pada umumnya memanfaatkan perangkat TIK mereka untuk aktivitas browsing, sosial media, dan chatting. Hasil dari penelitian ini menunjukkan bahwa banyaknya responden yang memanfaatkan perangkat TIKnya untuk aktivitas browsing, sosial media, dan chatting. Namun jika dilihat angka terbanyak dapat diketahui bahwa aktivitas chatting merupakan yang paling banyak dilakukan masyarakat Desa Argosari saat menggunakan perangkat TIK, ini disebabkan karena mereka menggunakan media chatting untuk berkomunikasi sesama warga desa ataupun berkomunikasi dengan client mereka. Temuan ini sesuai dengan hasil penelitian yang telah dilakukan oleh Heimerl et.al (2015) bahwa masyarakat rural pada umumnya menggunakan smartphone untuk berkomunikasi melalui fasilitas atau aktivitas chatting. Hasil ini juga didukung dengan pernyataan salah seorang responden bahwa:

\footnotetext{
"saya pakai smartphone sering untuk chatting dengan teman-teman saya diwhatsapp atau gak messenger mas, terkadang juga buat chatting dengan wisatawan yang pake jasa ojek saya buat naik ke puncak b29"”.
}

\section{Kondisi Demografis Berdampak Terhadap Perilaku Mengakses dan Pemanfaatan Informasi}

a. Hubungan Antara Usia dengan Aktivitas yang Dilakukan Saat Menggunakan Perangkat Teknologi

Berdasarkan hasil tabel silang di temukan bahwa adanya hubungan yang signifikan antara usia responden dengan aktivitas yang dilakukan masyarakat desa Argosari saat menggunakan perangkat teknologi. Merujuk pada hasil tabel tersebut diketahui bahwa semakin muda usia seseorang semakin mereka lebih memilih memanfaatkan smartphonenya untuk bersenang-senang seperti bermain game, atau bersosial media. Hal ini sesuai dengan hasil temuan Andone et.al (2016) yang menemukan bahwa semakin muda usia seseorang semakin mereka menggunakan smartphone untuk kegiatan yang menyenangkan. Andone et.al (2016) juga menemukan bahwa untuk orang yang lebih tua mereka kebutuhannya berbeda dengan yang masih remaja ataupun anak-anak, orangorang yang lebih tua cenderung menggunakan teknologi untuk berkomunikasi kesesama dan juga 
browsing untuk memenuhi kebutuhan informasinya. Hal ini juga sejalan dengan pendapat yang dikemukakan oleh Van Dijk (2012), bahwa terdapat perbedaan penggunaan perangkat teknologi berdasarkan tingkat pendidikan seseorang, di mana seseorang dengan tingkat pendidikan yang rendah cenderung menggunakan perangkat teknologi untuk hal-hal yang bersifat menyenangkan, sedangkan seseorang yang berpendidikan lebih tinggi cenderung menggunakan perangkat teknologi untuk hal-hal yang lebih penting dan serius.

Berdasarkan hasil tabel silang dapat ditarik kesimpulan bahwa responden yang berusia 36 tahun lebih, sebanyak 16 (88.9\%) dari total 18 responden yang berusia 36 tahun lebih cenderung menggunakan smartphonenya untuk melakukan aktivitas browsing. Pada kategori dewasa yang berusia 26-35 tahun, dapat ditarik kesimpulan bahwa 28 (100\%) atau seluruh responden yang berusia 26-35 tahun menggunakan perangkat teknologi untuk aktivitas chatting. Pada kategori remaja yang berusia 17-25 tahun, dapat disimpulkan bahwa seluruh remaja pada penelitian ini yang berjumlah 30 orang $(100 \%)$ seluruhnya melakukan aktivitas bersosial media ketika menggunakan perangkat teknologi. Sedangkan untuk kategori anak-anak dibawah 16 tahun dengan total 20 (83.3\%) dari total 24 responden (dapat dilihat pada tabel 3.2) lebih cenderung menggunakan perangkat teknologi dan akses internet untuk bermain games, baik itu yang online atau pun offline.

\section{b. Hubungan Antara Jenjang Pendidikan Terakhir dengan Skill Masyarakat dalam Mengoperasikan Fitur/Aplikasi Pada Perangkat Teknologinya}

Kesenjangan digital pada suatu daerah dapat diukur melalui tingkat atau skill yang dimiliki masyarakatnya dalam mengoperasikan perangkat keras (hardware) ataupun lunak (software) suatu teknologi. Kurangnya kemampuan atau skill seseorang dalam menggunakan perangkat teknologi disebabkan oleh rendahnya tingkat pendidikan seseorang atau kurangnya pelatihan dalam menggunakan perangkat teknologi tersebut (Putri, 2018). David (2015) juga menemukan hal yang serupa dalam penelitiannya bahwa salah satu alasan mengapa masyarakat rural banyak yang tidak memiliki skill atau kemampuan dalam penggunakan perangkat teknologi disebabkan oleh pihak sekolah yang ada di daerah rural tidak memiliki fasilitas atau laboratorium untuk siswanya belajar menggunakan perangkat teknologi tersebut. Van Deursen \& Vandijk (2010) menjelaskan bahwa faktor yang berpengaruh pada skill atau kemampuan masyarakat dalam menggunakan perangkat teknologi yaitu usia dan pendidikan. Maka dari itu, semakin tinggi pendidikan seseorang maka semakin tinggi skill atau kemampuan yang dimiliki dalam menggunakan atau mengoperasikan perangkat teknologi tersebut, baik dalam bidang hardware maupun softwarenya (Mantyastuti, 2016).

Berdasarkan hasil tabel silang ditemukan bahwa terdapat adanya hubungan antara jenjang pendidikan terakhir seseorang dengan skill atau kemampuan yang dimilikinya dalam mengoperasikan fitur/aplikasi pada perangkat teknologinya. Hal ini dibuktikan dengan temuan responden yang memiliki jenjang pendidikan terakhir SD sebanyak 71.7\%nya masih berada dalam tahap pengenalan atau belajar dalam mengoperasikan fitur/aplikasi yang ada pada perangkat teknologi. Sedangkan untuk responden yang memiliki jenjang pendidikan terakhir SMP 52.8\%nya sudah berada pada kategori terbatas dalam pengoperasian beberapa fitur/aplikasi yang ada pada perangkat teknologi. Data terakhir yang dapat diambil dari hasil tabel silang ialah responden yang memiliki jenjang pendidikan terakhir SMA, sebanyak $100 \%$ nya sudah berada pada kategori mampu mengoperasikan semua fitur/aplikasi yang ada pada perangkat teknologi. Dari seluruh data yang disebutkan diatas, kita dapat menarik kesimpulan bahwa temuan peneliti menunjukkan adanya hubungan antara jenjang pendidikan terakhir seseorang dengan tingkat skill atau kemampuannya dalam mengoperasikan fitur/aplikasi pada perangkat teknologi. Hal ini sesuai dengan pendapat yang dikemukakan oleh Robinson et.al (2003) bahwa masyarakat yang memiliki tingkat pendidikan yang lebih tinggi, maka mereka memiliki skill atau kemampuan yang lebih baik dalam mengoperasikan atau menggunakan suatu perangkat teknologi, serta mampu mendapatkan keuntungan dari skill atau kemampuannya dalam mengoperasikan perangkat teknologi tersebut.

\section{c. Hubungan Antara Jenjang Pendidikan Terakhir dengan Skill Masyarakat dalam Mengoperasikan Search Engine}

Peneliti menemukan adanya hubungan antara jenjang pendidikan terakhir yang ditempuk seseorang dengan skill atau kemampuan mereka dalam mengoperasikan search engine. Mantyastuti (2016) dalam penelitiannya menemukan kemampuan seseorang dalam mengoperasikan search engine dipengaruhi juga berdasarkan lama seseorang ketika mengakses internet, semakin lama orang tersebut mengakses internet setiap harinya maka semakin meningkat skill atau kemampuan mereka dalam mengoperasikan search engine. Hal ini sejalan dengan pendapat yang dikemukakan oleh Madden et.al (2005), bahwa seseorang yang terbiasa menggunakan internet akan meningkatkan kemampuannya saat mengoperasikan search engine.

Berdasarkan hasil tabel silang dapat diketahui adanya hubungan yang signifikan antara 
tingkat pendidkan terakhir seseorang dengan lama mereka mengakses internet setiap harinya. Dapat diketahui bahwa responden yang memiliki jejang pendidikan terakhir SD, sebanyak $47.8 \%$ menyatakan mengakses internet sehari hanya sekitar 1-2 jam saja. Responden yang jenjang pendidikan terakhirnya SMP, sebanyak 47.2\% mereka menghabiskan waktu 3-5 jam sehari dalam mengakses internet, sedangkan untuk responden yang jenjang pendidikan terakhirnya SMA, sebanyak 100\% responden mengakses internet lebih dari 5 jam setiap harinya. Hal ini tentu sejalan dengan temuan yang pernah dilakukan oleh Mantyastuti (2016) dan pendapat yang dikeluarkan oleh Madden et.al (2005). Namun hasil ini cukup berbeda dengan hasil penelitian yang dilakukan oleh Noviana (2016), bahwa semakin rendah jenjang pendidikan terakhir seseorang, maka semakin banyak waktu luang yang dimiliki mereka dan bisa dipergunakan untuk menggunakan smartphone. Berdasarkan hasil ini kita dapat tarik kesimpulan bahwa semakin lama seseorang mengakses internet maka semakin bagus kemampuan mereka dalam mengoperasikan search engine.

Berdasarkan data hasil dari tabel silang dapat diketahui adanya hubungan yang signifikan antara pendidikan terakhir dengan skill atau kemampuan seseorang dalam mengoperasikan search engine. Sebanyak $43.5 \%$ responden dengan jenjang pendidikan terakhirnya SD cenderung kurang mampu dalam mengoprasikan search engine, $47.2 \%$ responden dengan jenjang pendidikan terakhirnya SMP sudah mulai mampu dalam mengoperasikan search engine, sedangkan untuk $100 \%$ responden yang memiliki jenjang pendidikan terakhir SMA menyatakan bahwa mereka sangat mampu dalam mengoperasikan search engine. Berdasarkan hal tersebut dapat ditarik kesimpulan bahwa skill atau kemampuan warga Desa Argosari dalam mengoperasikan search engine masih tergolong biasa, dikarenakan sebanyak $48 \%$ dari total responden masih tidak mampu dan kurang mampu dalam mengoperasi search engine, sedangkan 52\% responden sudah merasa mampu dan sangat mampu dalam mengoperasikan search engine.

\section{d. Hubungan Antara Jenjang Pendidikan Terakhir dengan Kemampuan Masyarakat dalam Pemahaman Terhadap Konten yang Berbahasa Inggris}

Ketidakmampuan masyarakat rural dalam memahami sebuah konten berbahasa Inggris yang ada di internet merupakan salah satu penyebab terjadinya kesenjangan digital (Ariyanti, 2013). Ariyanti (2013) dalam penelitiannya juga menyampaikan bahwa masyarakat rural cenderung mengalami kesulitan dalam memahami konten atau isi informasi yang ada di internet karena kendala bahasa, masyarakat rural akan lebih mudah memahami informasi atau konten di internet yang berbahasa Indonesia. Sekitar $84 \%$ responden menyatakan bahwa mereka memilih jawaban mudah dan sangat mudah terkait tingkat pemahaman mereka akan konten yang berbahasa Indonesia, sedangkan untuk konten yang berbahasa Inggris diketahui bahwa 91\% responden menyatakan susah dan sangat susah terkait tingkat pemahaman mereka akan konten yang berbahasa Inggris. Hal ini terjadi dikarenakan tingkat pendidikan masyarakat rural tergolong cukup rendah untuk memahami konten atau informasi yang berbahasa Inggris (Ariyanti, 2013). Warga Desa Argosari menunjukkan rendahnya tingkat pendidikan yang mereka tempuh, dari 100 responden ditemukan bahwa $46 \%$ nya ada yang masih menempuh pendidikan SD dan ada yang hanya lulusan SD saja, dan 53\% responden merupakan lulusan SMP saja. Hanya 1 responden yang ditemukan peneliti yang merupakan lulusan SMA. Temuan ini sesuai dengan apa yang ditemukan oleh Mukhlis (2011), bahwa di desa tempat penelitiannya tingkat pendidikan masyarakatnya masih tergolong cukup rendah, karena hanya sedikit dari masyarakat desa tersebut yang melanjutkan pendidikannya sampai SMA ataupun perguruan tinggi. Berdasarkan hasil dari tabel silang dapat diketahui adanya hubungan yang signifikan antara jenjang pendidikan terakhir seseorang dengan pemahaman mereka terhadap konten berbahasa Inggris. Berdasar tabel diatas dapat diketahui bahwa 73.9\% dari responden yang memiliki status jenjang pendidikan terakhir SD, menyatakan bahwa mereka merasa sangat susah dalam memahami konten berbahasa Inggris. Responden yang memiliki status jenjang pendidikan terakhir SMP, sebanyak 52.8\% mengaku susah dalam memahami konten yang berbahasa Inggris, sedangkan untuk $100 \%$ responden yang memiliki jenjang pendidikan terakhir SMA mengaku bahwa mereka mudah dalam memahami konten bahasa inggris. Berdasarkan data tersebut dapat ditarik kesimpulan bahwa semakin tinggi pendidikan seseorang makin mudah mereka dalam memahami konten yang berbahasa inggris, hal ini sejalan dengan pendapat yang dikemukan oleh Ariyanti (2013) bahwa semakin tinggi pendidikan seseorang maka akan lebih mudah memahami sebuah konten yang berbahasa Inggris dibandingkan dengan tingkat pendidikan 


\section{Simpulan}

Gambaran kesenjangan digital pada aspek infrastruktur di desa Argosari sudah cukup berkembang, dikarenakan untuk angka kepemilikan perangkat teknologi smartphone responden berada pada angka 100\%. Sedangkan untuk ketersediaan infrastruktur pendukung yaitu akses internet masih terbilang sangat kurang, karena di desa Argosari hanya terdapat 1 provider saja yang menyediakan akses internet jaringan Telkomsel. Akan tetapi untuk sebagian dusun yang ada dibagian atas pegunungan desa Argosari masih belum tercapai jaringan dari telkomsel tersebut. Gambaran kesenjangan digital pada aspek skill atau kemampuan di desa Argosari masih rendah, dikarenakan sebanyak 64\% responden masih dalam tahap pengenalan atau belajar dalam menggunakan perangkat teknologinya (perangkat keras / hardware). Kemampuan masyarakat desa Argosari dalam menghubungkan perangkat teknologinya dengan internet masih kurang mampu. Sebanyak $100 \%$ responden sudah memiliki perangkat teknologi smartphone, akan tetapi masih terdapat $31 \%$ dari mereka yang kurang mampu dan bahkan $17 \%$ lainnya tidak mampu sama sekali dalam mengakses internet. Seluruh smartphone responden sudah terinstall aplikasi web browsing Google Chrome, akan tetapi hanya 39\% yang mengaku mampu dalam mengoperasikan fasilitas search engine yang ada di internet. Gambaran kesenjangan digital pada aspek pemahaman konten bahasa di desa Argosari juga tergolong masih sangat kurang. Hal ini dikarenakan sebanyak 51\% responden kurang menguasai bahasa Inggris, bahkan 37\% lainnya sama sekali tidak menguasai bahasa Inggris. Kemampuan mereka dalam memahami konten yang berbahasa Inggris bahkan lebih buruk. Sisi lain menunjukkan untuk kemampuan responden dalam berbahasa Indonesia sudah sangat baik, sekitar $46 \%$ responden mengaku telah menguasai bahasa Indonesia, dan 49\% responden lainnya mengaku sangat menguasai bahasa Indonesia. Kemampuan mereka dalam memahami konten yang berbahasa Indonesia juga sangat bagus.

Terdapat hubungan antara usia dengan aktivitas yang dilakukan masyarakat Desa Argosari saat menggunakan perangkat teknologi. Hal ini ditunjukkan dari hasil tabel silang (crosstab) bahwa semakin muda usia masyarakat desa Argosari maka semakin mereka menggunakan perangkat teknologinya untuk aktivitas yang menyenangkan atau menghibur seperti bermain game, dengan persentase $36.4 \%$. Terdapat hubungan antara jenjang pendidikan terakhir dengan skill masyarakat Desa Argosari dalam mengoperasikan fitur/aplikasi pada perangkat teknologinya. Hal ini ditunjukan dari hasil tabel silang (crosstab) bahwa semakin rendah jenjang pendidikan masyarakat desa Argosari maka semakin rendah juga skill atau kemampuan mereka dalam mengoperasikan fitur/aplikasi pada perangkat teknologinya, sehingga membuat mereka masih dalam tahap pengenalan atau belajar dalam mengoperasikan fitur/aplikasi yang ada pada perangkat teknologi, dengan persentase $71.7 \%$. Terdapat hubungan antara jenjang pendidikan terakhir dengan skill masyarakat Argosari dalam mengoperasikan search engine. Hal ini ditunjukkan dari hasil tabel silang (crosstab) bahwa semakin rendah jenjang pendidikan masyarakat desa Argosarimaka semakin rendah juga skill atau kemampuan mereka, sehingga membuat mereka kurang mampu dalam mengoperasikan fitur search engine, dengan persentase 43.5\%. Hal ini terjadi juga dipengaruhi oleh semakin jarang seseorang mengakses internet maka semakin rendah juga kemampuan mereka dalam mengoperasikan search engine. Terdapat hubungan antara jenjang pendidikan terakhir dengan kemampuan masyarakat terhadap konten yang berbahasa Inggris. Hal ini ditunjukkan dari hasil tabel silang (crosstab) bahwa semakin rendah jenjang pendidikan masyarakat desa Argosari maka semakin rendah juga kemampuan mereka dalam memahami konten yang berbahasa Inggris, dengan persentase $73.9 \%$.

\section{Referensi}

Aaker, D. A., V. Kumar, \& George, S. (1995). Marketing Research. Canda: Jon Wileyand Sons, Inc. Andone, I., Blaszkiewicz, K., Eibes, M., \& Trendafilov, B. (2016). How Age and Gender Affect Smartphone Usage. Institute of Computer Science.

Ariyanti, S. (2013). Studi Pengukuran Digital Divide di Indonesia (Study of Digital Divide Measurement In Indonesia. Puslitbang Sumber Daya dan Perangkat Pos dan Informatika, 281- 292.

Asosiasi Penyelenggara Jasa Internet Indonesia. (2016). INFOGRAFIS: Penetrasi \& Perilaku Pengguna Internet Indonesia.

Asosiasi Penyelenggara Jasa Internet Indonesia. (2017). INFORGRAFIS: Peneterasi dan Pengguna Internet 
Bungin, B. (2005). Metode Penelitian Kuantitatif. Jakarta: Prenadamedia.

Chisenga, J., Entsua-Mensah, C., \& Sam, J. (2007). Impact of Globalization on the Information Needs of Farmers in Ghana: A Case Study of Small-Scale Poultry Farmers.

David, N. (2015). Information Communication Technology In Rural Schools Of Nigeria: Case Study Engu State, Nigeria. Deparment of Electronic Engineering.

De Marco, A., \& Vernon-Feagans, L. (2013). Rural Neighborhood Context, Child Care Quality, and Relationship to Early Language Development. Early Education and Development, 792-812.

Hadiyat, Y. D. (2014). Kesenjangan Digital di Indonesia (Studi Kasus di Kabupaten Wakatobi). Pekomnas, 81-90.

Heimerl, K., Menon, A., Hasan, S., Ali, K., Brewer, E., \& Parikh, T. (2015). Analysis of Smartphone Adoption and Usage in a Rural Community Celular Network. Computer Science, 1-4.

Huzaini, A. (2014). Interaksi Sosial Masyarakat Dalam Perspektif Sosilogi Pedesaan Pasca Konflik Sunny Syiah di Desa Lar-Lar Kecamatan Banyuates Kabupaten Sampang. Skripsi.

Kementerian Komunikasi dan Informatika Republik Indonesia. (2016). Infografis Indikator TIK.

Lloyd, J. E., \& Hertzman, C. (2010). How Neighborhoods Matter for Rural and Urban Children's Language and Cognitive Development at Kindergarten and Grade 4. Journal of Community Psychology, 293-313.

Madden, A. (2005). Using the Internet in Teaching: the Views of Practitioners. British Journal of Educational Technology, 255-280.

Mantyastuti, Y. A. (2016). Digital Divide dikalangan santri Pondok Pesantren Salaf (Studi Deskriptif Tentang Kesenjangan Digital dikalangan Santri Pondok Pesantren di Kabupaten Rembang. Skripsi.

Mukhlis, A. (2011). Faktor-Faktor yang Mempengaruhi Rendahnya Tingkat Pendidikan Masyarakat di Desa Dieng Wetan Kecamatan Kejajar Kabupaten Wonosobo. Skripsi.

Noviana, A. P. (2016). Hubungan Tingkat Penggunaan Smartphone pada Remaja dengan Interaksi dalam Keluarga. Skripsi.

Organization for Economic Co-Operation and Development. (2001). Understanding the Digital Divide. Paris: OECD Publication.

Putri, W. C. (2018). Kesenjangan Digital Pada Kalangan Remaja. Skripsi.

Robinson, J. P., DiMaggio, P., \& Hargittal, E. (2003). New Social Survey Perspectives on the Digital Divide. IT \& Society, 1-22.

Saefi. (2015). Pengaruh Akses Informasi, Dukungan Orang Tua dan Lingkungan Sekolah Terhadap Minat Siswa Kelas XIIJurusan Administrasi Perkantoran Melanjutkan ke Perguruan Tinggi di SMK Negeri 1 Kebumen. Skripsi.

Soekanto, S. (2006). Sosiologi Suatu Pengantar. Jakarta: Raja Grapindo Persada.

Subiakto, H. (2013). Internet untuk Pedesaan dan Pemanfaatannya Bagi masyarakat. Masyarakat, Kebudayaan, dan Politik, 243-256.

Tayo, O., Thompson, R., \& Thompson, E. (2015). Impact of the Digital Divide on Computer Use and Internet Access on the Poor in Nigeria. Journal of Education and Learning.

Tustin, D. H. (2012). Digital Divide and Inequality Among Digital Native: A South African Perspective. African Journal of Businesss Management.

Van Deursen, A. J., \& Van Dijk, J. A. (2010). Internet Skills and Digital Divide. Journal New Media and Society, 893-911.

Van Deursen, A. J., \& van Dijk, J. A. (2013). The Digital Divide Skhifts to Differences in Usage.

Van Dijk, J. (2006). The Network Society: Second edition. London: Sage Publishing Inc.

Van Dijk, J. A. (2012). The Evolution of the Digital Divide: The Digital Divide turns to inequality of Skills and Usage. The Evolution of the Digital Dividie, 57-75. 